\title{
ANALISIS PERBANDINGAN VOLUME PERDAGANGAN SAHAM SEBELUM DAN SESUDAH STOCK SPLIT DI BEI
}

\author{
Nur Erika Jayanti \\ Vitayanti Fattah \\ Program Studi S1 Manajemen Fakultas Ekonomi Universitas Tadulako \\ email: nurerikajayanti@gmail.com
}

\begin{abstract}
This study aims to determine differences in stock trading volume before and after the announcement of a stock split in manufacturing companies on the Indonesia Stock Exchange in the 2014-2018 period. The population in this study were 60 manufacturing companies listed on the Stock Exchange and those who met the sampling criteria were 30 companies. The sampling method uses a purposive sampling technique. This research is an event study of the activity of stock trading volume 4 days before and after the issuer conducts a stock split. This study uses the Kolmogorov-Smirnov test to test data normality. Data analysis was performed using the Wilcoxon Signed Rank Test non parametric statistical test. . The results showed that the $P$ value (sig 2 tailed) was 0.221 . Because of $P$ value (sig) 0.221> $\alpha 0.05, H_{0}$ is accepted and $H_{1}$ is rejected. So this study states that there is no significant difference in the volume of stock trading during the period before and after the stock split.
\end{abstract}

Keywords: Stock Split, Trading Volume

Penelitian ini bertujuan untuk mengetahui perbedaan volume perdagangan saham sebelum dan sesudah pengumuman stock split pada perusahaan manufaktur di Bursa Efek Indonesia periode 2014-2018. Populasi dalam penelitian ini sebanyak 60 perusahaan menufaktur yang terdaftar di BEI dan yang memenuhi kriteria penarikan sampel sebanyak 30 perusahaan. Metode penarikan sampel menggunakan teknik purposive sampling. Penelitian ini merupakan event study dari aktivitas volume perdagangan saham 4 hari sebelum dan sesudah emiten melakukan stock split. Penelitian ini menggunakan uji Kolmogorov-Smirnov untuk menguji normalitas data. Analisis data dilakukan menggunakan uji statistik non parametrik Wilcoxon Signed Rank Test. . Hasil penelitian menunjukkan bahwa nilai $\mathrm{P}$ value (sig 2 tailed) sebesar 0,221. Oleh karena $\mathrm{P}$ value (sig) $0,221>\alpha 0,05$, maka $\mathrm{H}_{0}$ diterima dan $\mathrm{H}_{1}$ ditolak. Sehingga penelitian ini menyatakan bahwa tidak terdapat perbedaan yang signifikan volume perdagangan saham pada saat periode sebelum dan sesudah pemecahan saham.

\section{Kata Kunci: Stock Split, Volume Perdagangan}

\section{PENDAHULUAN}

Pasar modal dapat menjadi suatu alternatif investasi bagi pihak-pihak yang kelebihan dana diluar sistem perbankan yang dapat menjanjikan tingkat keuntungan. Investor di pasar akan memilih emiten yang memiliki prospek yang baik agar dapat memperoleh keuntungan maksimal. Menurut Eduardus (2010) pasar modal merupakan perjumpaan dengan kelompok yang mempunyai banyak modal untuk kelompok yang memerlukan uang dengan memperdagangkan surat berharga, lokasi terjadi jual beli surat berharga disebut bursa efek. Martalena (2011) mendeskripsikan pasar modal terdapat dua kata yaitu pasar dan modal, sehingga pasar modal dapat diartikan menjadi lokasi ajakan dan negosiasi terhadap modal baik berbentuk ekuitas maupun jangka panjang. Pada dasarnya, pasar modal berperan penting bagi perekonomian suatu negara. Pasar modal bertujuan untuk memperoleh tambahan dana atau sebagai modal usaha dari masyarakat. Menurut Inayatus (2016) pasar modal menjadi sarana bagi masyarakat untuk berinvestasi pada catatan keuangan seperti saham, obligasi, reksadana serta aset-aset pasar lainnya. Pasar modal suatu contoh sistem ekonomi yang turut berpengaruh terhadap pertumbuhan serta evolusi perekonomian dan bisnis.

Salah satu pengumuman di pasar modal ialah pengumuman pemecahan saham. Informasi yang terdapat di pasar modal memiliki makna apabila pengumuman pemecahan saham berdampak baik kepada pemilik dana sehingga melangsungkan negosiasi di pasar modal, beberapa contoh 
pemecahan saham yaitu harga saham, volume perdagangan dan indikator lain (Gunasih dan Irfan, 2015). Dalam pembukuan laporan catatan perusahaan dapat diperoleh berbagai informasi yang dibutuhkan dalam tahap evaluasi untuk pengambilan keputusan oleh calon pemilik dana. Salah satu informasi yang berguna bagi seorang investor ialah informasi mengenai aksi korporasi, sehingga dalam aksi korporasi yang dilaksanakan perusahaan yaitu melakukan stock split. Oleh karena itu, terdapat dua jenis stock split adalah stock split up dan stock split down.

Pengumuman stock split merupakan salah satu informasi yang bermanfaat untuk pemilik dana dalam perencanaan pengambilan keputusan. Pengumuman informasi yang disampaikan oleh pasar modal dapat menjadi acuan investor dalam menurunkan ketidakpastian keputusan sehingga hasil keputusan yang ditetapkan dapat searah dengan keinginan investor. Kemunculan negosiasi pada pasar modal merupakan dampak dari pengumuman informasi yang disampaikan, sehingga hasil yang didapat dalam pengamatan volume perdagangan saham, dan harga pasar saham terdapat keuntungan instansi (Lestari, 2008:139). Stock split merupakan bentuk aksi korporasi yang tersedianya informasi secara menyeluruh untuk memberikan dampak positif kepada kelompok yang terdapat di pasar modal, sehingga memberikan manfaat kepada pemegang saham sebab dapat mempengaruhi hasil saham, struktur kepemilikan saham, dan aktivitas nilai saham yang sedang berlangsung (Boedhi, 2011:63). Informasi yang disampaikan investor berfokus terhadap strategi yang diterapkan perusahaan pada pengumuman stock split. Pada saat pengumuman dipublikasikan maka masyarakat akan secara spontan menyepakati dan menyimak informasi yang telah dipublikasikan. Sehingga timbul pertanyaan apakah informasi tersebut memiliki dampak positif terhadap nilai perusahaan yang hasilnya akan memberikan keuntungan atau tidak kepada pemegang saham.

\section{KAJIAN LITERATURE}

\section{Signalling Theory}

Signalling Theory berpendapat jika stock split dapat menyapaikan berita ke investor mengenai prospek dalam penaikan return pada masa depan yang subtansial (Marwata, 2001). Menurut teori ini, apabila harga saham sangat tinggi maka perlu dilaksankan stock split untuk harga saham menjadi optimal pada kisaran harga tertentu (Anshuman dan Avner, 2012). Apabila harga pada presplit meningkat, maka pemecahan saham menguatkan kebenaran pada motif tersebut (Leungb, et al. 2006). Menurut Latifah (2008) tentang trading range theory bahwa manajemen melakukan stock split karena didorong oleh perilaku pasar yang menganggap bahwa dengan melakukan stockb split dapat mengembalikan harga saham ke titik optimal yang tidak terlalu mahal sehingga investor ingin membeli, transaksi meningkat sehingga meningkatkan jumlah volume perdagangan.

\section{Trading Range Theory}

Teori ini diartikan juga sebagai teori likuiditas, trading range theory menjelaskan jika stock split menaikkan tingkat likuiditas perdagangan saham. Perusahaan yang memiliki harga saham yang terlalu tinggi meyebabkan kurang aktifnya saham dalam perdagangan atau statistik, maka disebabkan oleh menurunnya daya beli investor untuk saham tersebut sehingga perusahaan melaksanakan stock split (Margasari, 2009).

\section{Volume Perdagangan}

Menurut Ayu (2015) volume perdagangan saham dapat menjadi suatu indikator dalam menentukan ada tidaknya reaksi pasar terhadap suatu kejadian tertentu yang berkaitan dengan jualbeli saham. Meningkatnya aktivitas volume perdagangan saham dapat diketahui dengan mengukur menggunakan trading volume activity. Trading volume activity ialah salah satu persamaan yang menunjukkan angka perbandingan terhadap jumlah saham yang diperjualkan dalam waktu tertentu dengan jumlah saham yang beredar pada waktu tertentu. Volume perdagangan ialah sebuah instrumen yang dipakai dalam melihat reaksi pasar modal berdasarkan berita melalui parameter 
volume saham yang diperjualkan di pasar (Shobriati, Darminto, \& Endang, 2013). Kemudian volume perdagangan saham ialah jumlah satuan unit saham yang diperdagankan atau dijual pada periode tertentu, biasanya harian (Sutrisno \& Yuniartha, 2000).

\section{Pasar Modal}

Menurut Robert Ang dan Hadi (2013) pasar modal adalah situasi yang mana memberikan ruang dan peluang antara penjual dan pembeli bertemu dan bernegosiasi dalam pertukaran komoditas dan kelompok komuditas modal. Modal dalam artian berupa hutang maupun modal ekuitas, tempat pertukaran inilah yang disebut pasar modal (bursa efek). Dalam UUPM no.8/1995 mengenai ketentuan umum pengertian bursa efek ialah pihak yang melaksanakan dan mempersiapkan sistem dan sarana untuk menyatukan penawaran jual dan beli efek serta aset dengan manfaat memperjualkan efek di antara mereka. Efek merupakan surat berharga pengakuan hutang, surat berharga komersial saham, obligasi, tanda bukti utang, unit penyertaan investasi kolektif, kontrak berjangka atas efek dan deviratif dari efek (Robert Ang, 1995).

\section{Fungsi Pasar Modal}

Dalam sistem perekonomian pasar modal memiliki dua manfaat, ialah fungsi ekonomi dan keuangan. Dalam manfaat ekonomi pasar modal memfasilitasi dalam memindahkan modal dari pihak pemilik modal lebih (lender) ke pihak yang membutuhkan modal jangka panjang dalam rangka pembiayaan, lender mengharapkan return dari investasi tersebut. Sedangkaan fungsi keuangan menyediakan modal dari lender ke borrower tanpa terlibat langsung dalam kepunyaan aktiva (Hadi, 2013).

\section{Karakteristrik Pasar Modal}

Menurut Hadi (2013) pasar modal merupakan lembaga yang teroganisir yang menjadikan sarana transaksi sekuritas sehingga dilihat dari struktur dan bentuk pasar yang berbeda dari jenis pasar lainnya, untuk itu pasar modal memiliki karakteristik sebagai berikut:

1. Membeli prospek yang akan datang, karakter investasi yang memberikan keuntungan prospek yang akan datang (expected return), semua investor yang memegang sekuritas didasarkan pengharapan di masa datang baik dalam jangka pendek maupun jangka panjang.

2. Mengharapkan keuntungan yang tinggi dengan resiko yang tinggi. Hal ini sejalan dengan teori investasi yang memberikan expected return tinggi yang mengandung risk yang tinggi.

3. Mengutamakan kemampuan analisis. Analisis dalam pasar modal sangat penting karena dapat menentukan return dan risiko dalam berinvestasi. Keharusan untuk memaksimalkan analisis teknikal dan fundamental untuk melihat prospek di masa depan.

4. Mengandung unsur spekulasi. Pasar modal memiliki nilai spekualasi tinggi karena pengaruh dari luar maupun dalam. Khususnya dalam investor, yang mengincar capital gain karena jangka pendek setiap saat harga dapat naik dan turun dengan tidak terdeteksi.

\section{Stock Split}

Stock split adalah pemecahan angka saham menjadi nominal lebih kecil (Robert Ang, 1997). Stock split merupakan salah satu corporate action yang dapat dilakukan oleh perusahaan yaitu, strategi perusahaan berguna untuk meningkatkan likuiditas saham perusahaan tersebut. Menurut Jogiyanto (2003) menyatakan bahwa stock split ialah memecahkan lembar saham menjadi n lembar sehingga harga saham perlembar dengan nilai nominal yang baru ialah sebesar $1 / \mathrm{n}$ dari biaya saham sebelumnya. Perusahaan melaksanakan pemecahan bertujuan agar sahamnya berada dalam rentang penjualan menjadi optimal dan distribusi saham menjadi lebih luas, daya beli investor meningkat terutama untuk investor perseorangan dengan dana yang terbatas (Sulistiyono, 2011).

\section{Tujuan Stock Split}


Manfaat stock split 'dari para pelaku pasar khususnya emiten adalah sebagi berikut (Hendrawaty, 2007):

1. Meningkatkan daya tarik investor individual dengan daya beli kecil untuk melakukan investasi.

2. Harga saham yang lebih rendah setelah dilakukan stock split menarik minat investor untuk membeli saham tersebut dengan jumlah yang banyak.

3. Sinyal positif bagi pasar bahwa kinerja perusahaan memeliki prospek yang bagus kedepannya.

4. Meningkatkan jumlah pemegang saham sehingga lebih likuid.

\section{Prosedur Stock Split}

Menurut Hadi (2013) cara stok split dilakukan dengan prosedur menukarkan saham dengan nilai nominal lama ke saham baru dengan nominal baru. Proses pelaksanaan mengikuti jadwal stock split yang telah ditetapkan emiten. Adapun isi jadwal stock split paling tidak memuat hal-hal, antara lain:

1. Tanggal mulai permohonan pengganti SKS lama untuk stock split. Merupakan tanggal dimulainya penggantian Surat Kolektif Saham (SKS) lama, pada tanggal pemegang saham dalam melakukan pendaftaran saham yang dimiliki untuk ditukarkan dengan saham baru dengan nilai nominal baru. Pada periode ini sampai dengan periode suspense dimulai, saham dengan nilai nominal lama masih dapat diperdagangkan dan pemegang saham lama selama periode ini boleh mendaftarkan diri untuk stock split.

2. Periode suspense, periode dimana saham dengan nilai nominal lama sudah tidak dapat lagi diperdagangkan. Di sini memberikan kesempatan untuk mengadministrasikan saham untuk stock split.

3. Tanggal mulai menyerahkan SKS baru hasil stock split. Pada tanggal tersebut menyerahkan SKS baru hari stock split diserahkan pada pemegang saham.

4. Tanggal mulai perdagangan saham, tanggal dimana saham baru dengan nilai nominal baru hasil stock split dapat diperdagangkan di lantai bursa, sesusai dengan jadwal yang telah ditetapkan, Biasanya tanggal saham baru hasil stock split dapat diperdagangkan di bursa bersamaan dengan tanggal penyerahan SKS saham baru stock split.

\section{Dampak Stock Split}

Menurut Kabo (2013), ternyata ditemukan jika stock split memiliki dampak terhadap:

a. Harga Saham. Pada hakekatnya pemecahan saham dilaksanakan apabila telah terjadi penaikan biaya saham. Menurut pandangan perusahaan, pemecahan saham dapat diharapkan memberi reaksi ke pasar secara positif dalam stock price. Selama pemecahan, angka nominal saham menjadi kurang mengikuti split faktornya. Kurangnya angka nominal diharapkan akan diikuti dengan kurangnya biaya saham ketingkat penjualan. Dampak pemecahan saham terhadap biaya saham diantaranya ialah:

1. Rata-rata biaya saham suatu perusahaan akan naik pada berapa lama ketika telah melaksanakan pengumuman pemecahan saham.

2. Apabila suatu perusahaan menyampaikan adanya pemecahan saham, biaya sahamnya akan cenderung naik. Tetapi apabila selama beberapa bulan ke depan perusahaan tidak melakukan poengumuman terhadap adanya kenaikan profit, maka biaya sahamnya akan kembali jatuh ketingkat sebelumnya.

3. Peningkatan biaya lebih cenderung terjadi akibat adanya fakta jika para investor melaksanakan pemecahan saham sebagai tanda adanya profit di masa depan yang lebih tinggi daripada adanya harapan untuk pemecahan saham. Karena cenderung akan memecahkan saham ialah manajemen yang berfikir terlihat baik, maka pengumuman akan 
adanya pemecahan dianggap sebagai tanda apabila profit kemungkinan besar akan meningkat. Oleh karena itu, penaikkan biaya yang dikaitkan dengan pemecahan saham kemungkinan merupakan dampak dari sinyal akan adanya prospek profit dan dividen yang menguntungkan, dan bukannya karena minat atas pemecahan saham itu sendiri.

4. Komisi biasanya secara persen dibebankan lebih meningkat dari saham yang berbiaya rendah. Sehingga diartikan menjual beli saham berbiaya rendah ternyata mahal dari pada saham berbiaya tinggi, dan selanjutnya mempunyai arti jika pemecahan ini dapat mengurangi likuiditas saham perusahaan. Bukti ini menjelaskan apabila pemecahan saham pada umumnya dapat berbahaya walaupun biaya lebih rendah berarti lebih banyak investor yang mampu membeli lot lengkap (100 lembar) yang mempertanggungkan harga lebih rendah dari pada lot ganjil (kurang dari 100 saham).

b. Volume Perdagangan Saham.

Stock split memiliki dampak ke volume perdagangan dan jumlah pemilik saham yang dalam hal ini ialah semakin meningkat. Sehingga dapat disebabkan karena apabila harga saham yang dijanjikan tidak tinggi (rendah) maka banyak investor yang berminat dalam membeli saham tersebut sebab volume perdagangannya meningkat akibat dari saham tersebut aktif diperjualkan.

c. Frekuensi Perdagangan Saham.

Frekuensi perdagangan saham ialah berapa kali terjadinya jual beli pada saham yang tersangkut pada waktu tertentu. Dengan melaksanakan pemecahan maka biaya saham relatif rendah sehingga terjadinya jual/beli pada saham yang bersangkutan tersebut akan meningkat. Dengan frekuensi transaksi penjualan saham dapat diketahui akan diminati investor atau tidak.

d. Return Saham.

Sesudah kejadian stock split harga saham cenderung turun untuk kemudian naik kembali. Sehingga saham yang diperdagangkanpun akan semakin likuid dan diminati oleh para investor. Dengan adanya kenaikan harga saham tersebut maka akan diikuti dengan kenaikan return saham. Hal ini juga menjadi salah satu alasan investor tertarik dengan saham tersebut yang melakukan stock split.

e. Volatilitas Harga Saham.

Terjadinya peningkatan volatilitas biaya saham apabila pemecahan saham dapat berakibat adanya price discretness dan presentasi bid ask spread pada saham yang bernilai rendah.

\section{METODE PENELITIAN}

Penelitian ini memakai metode pendekatan kuantitatif dengan jenis penelitian verifikatif. Penelitian ini ialah suatu studi yang termasuk kedalam kategori event study, event study adalah penelitian yang mengetahui reaksi market terhadap suatu peristiwa yang informasinya diumumkan sebagai suatu pemberitahuan (Jogiyanto, 2003).

Sampel instansi manufaktur yang melaksanakan stock split dari periode 2014-2018. Pemilihan sampel yang digunakan adalah sampel judgement sampling yang memilih anggotaanggota sampel yang sesuai dengan beberapa kriteria tertentu atas dasar catatan yang lalu atau tujuan penelitian yang ingin dicapai (Wijaya, 2013). Berikut kriteria penentuan sampel pada penelitian ini:

1. Perusahaan Manufaktur yang terdaftar di Bursa Efek Indonesia (BEI) pada periode 2014-2018.

2. Perusahaan Manufaktur yang terdaftar di Bursa Efek Indonesia (BEI) minimal 4 hari sebelum dan sesudah stock split. Digunakan 4 hari sebelum dan sesudah stock split karena efek stock split cenderung tidak akan lama, oleh karena itu digunakan rentan waktu 4 hari agar penelitian ini tidak bias. 


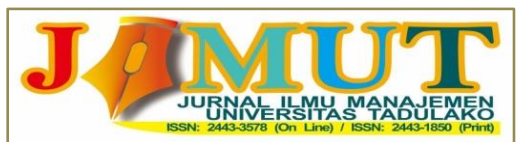

Vol. 7, No 1, Januari 2021, 001-011

3. Perusahaan yang hanya melakukan kebijakan aksi korporasi stock split tanpa melakukan kebijakan lain seperti warrant, right issue, dividen saham, dan pengumuman lainnya. Tanggal stock split tidak bersamaan dengan kejadian lain yang secara langsung dapat mempengaruhi harga dan volume perdagangan saham.

4. Perusahaan Manufaktur yang mempunyai volume perdagangan selama 4 hari sebelum dan sesudah stock split.

5. Perusahaan Manufaktur yang aktif diperdagangkan selama 4 hari sebelum dan sesudah stock split.

6. Perusahaan Manufaktur yang datanya tersedia secara lengkap untuk kebutuhan analisis.

Berdasarkan kriteria tersebut, maka jumlah emiten yang menjadi sampel ada 30 perusahaan. Data diperoleh dari laporan tahunan perusahaan yang listing di Bursa Efek Indonesia.

\section{HASIL DAN PEMBAHASAN}

Berikut ini adalah data rata-rata trading volume activity pada perusahaan manufaktur 20142018:

Tabel 1. Rata-Rata Trading Volume Activity

\begin{tabular}{|c|c|c|c|}
\hline No & Emiten & Sebelum & Sesudah \\
\hline 1. & ALMI & 0,0000005 & 0,0001905 \\
\hline 2. & LTLS & 0,0006885 & 0,0012459 \\
\hline 3. & CEKA & 0.0000130 & 0,0000369 \\
\hline 4. & MERK & 0,0000142 & 0,0002824 \\
\hline 5. & HMSP & 0,0001787 & 0,0001381 \\
\hline 6. & PSAB & 0,0012761 & 0,0006259 \\
\hline 7. & IMPC & 0,0002755 & 0,0003767 \\
\hline 8. & KREN & 0,0010471 & 0,0016514 \\
\hline 9. & ASBI & 0,0000903 & 0,0002612 \\
\hline 10. & ICBP & 0,0004478 & 0,0003227 \\
\hline 11. & KICI & 0,0001901 & 0.0000750 \\
\hline 12. & ITMA & 0,0002011 & 0,0002323 \\
\hline 13. & TOTO & 0,0015088 & 0,0005387 \\
\hline 14. & SMSM & 0.0000340 & 0,0001072 \\
\hline 15. & KKGI & 0.0004490 & 0,0000696 \\
\hline 16. & IIKP & 0,0064105 & 0,0067025 \\
\hline 17. & SMDR & 0,0004711 & 0,0010264 \\
\hline 18. & ULTJ & 0,0000052 & 0,0000702 \\
\hline 19. & BMRI & 0,0006109 & 0,0006517 \\
\hline 20. & INAI & 0,0001118 & 0.0002510 \\
\hline 21. & BBRI & 0,0006515 & 0,0012747 \\
\hline 22. & MKNT & 0,0009027 & 0,0018565 \\
\hline 23. & TPIA & 0,0004459 & 0,0005848 \\
\hline 24. & PTBA & 0,0032241 & 0,0011905 \\
\hline 25. & TOWR & 0,0000324 & 0,0000637 \\
\hline 26. & TOPS & 0.0014790 & 0,0034875 \\
\hline 27. & GEMA & 0.0000800 & 0,0002682 \\
\hline 28. & MARI & 0,0069612 & 0,0033349 \\
\hline 29. & BUVA & 0,0020489 & 0,0016256 \\
\hline 30. & KPIG & 0,0001052 & 0,0003502 \\
\hline \multicolumn{2}{|c|}{ RATA-RATA } & 0,001116004 & 0,001020246 \\
\hline
\end{tabular}

Sumber : www.idx.co.id

Perusahaan yang mempunyai volume perdagangan saham tertinggi sebelum stock split adalah MARI. Saat pengumuman stock split, perusahaan MARI bukan perusahaan yang memiliki volume 
saham tertinggi melainkan (TOPS) diantara 30 perusahaan yang ada. Volume perdagangan saham saat pengumuman stock split mengalami peningkatan. Hal ini menandakan bahwa pengumuman stock split berdampak baik, karena meningkatkan likuiditas perdagangan saham, walaupun mungkin tidak terlalu tinggi peningkatannya. Jika TOPS mempunyai volume perdagangan saham tertinggi, CEKA justru mempunyai volume perdagangan saham terendah saat pengumuman stock split. Ini terjadi kemungkinan karena investor menganggap bahwa pengumuman stock split yang dilakukan perusahaan CEKA tidak dapat menyejahterakan di masa mendatang.

Sesudah dilakukannya stock split, perusahaan TOPS merupakan perusahaan yang mempunyai volume perdagangan saham tertinggi diantara 30 perusahaan sebagai sampel. Pada hari terakhir $(\mathrm{t}+4)$ dilakukannya stock split, volume perdagangan saham mengalami peningkatan. Artinya saham perusahaan TOPS likuid di pasar bursa atau banyak yang melakukan transaksi. Hal lain justru terjadi pada perusahaan CEKA, sebelum dilakukannya stock split volume perdagangan saham memang cukup rendah. Namun sesudah dilakukannya stock split, perusahaan CEKA justru mengalami penurunan volume perdagangan saham. Hal ini dapat diartikan bahwa saham perusahaan CEKA sesudah stock split tidak mengalami likuid. Jika sesudah stock split tidak terjadi peningkatan sama sekali volume perdagangan saham, kemungkinan perusahaan CEKA tidak menyampaikan informasi valid ke publik, sehingga berdampak pada menurunnya volume perdagangan saham. Bahkan CEKA merupakan perusahaan yang mempunyai volume perdagangan saham terendah diantara 30 perusahaan sesudah dilakukannya stock split.

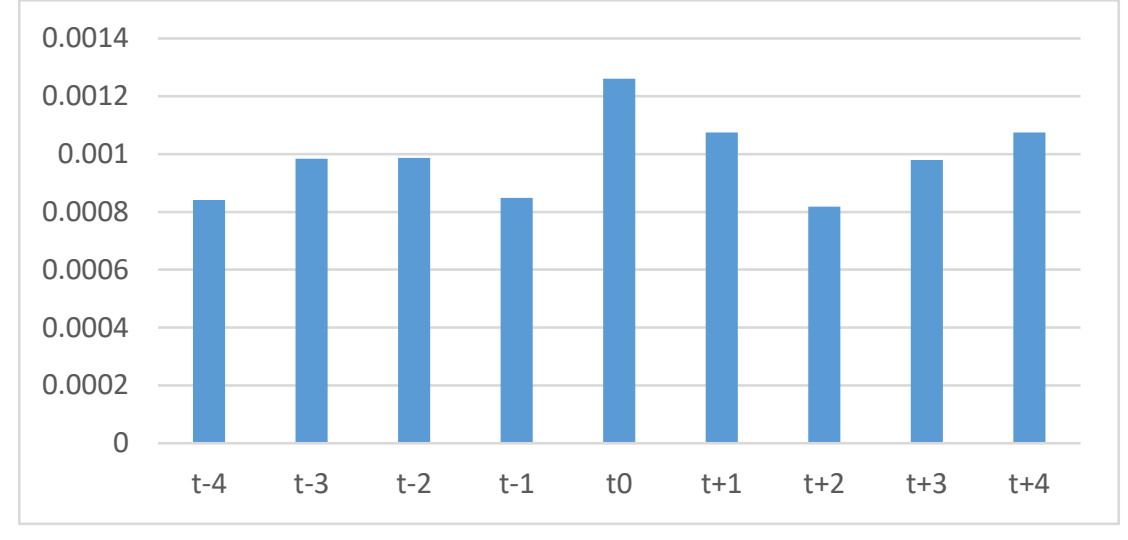

Gambar. 1. (a) Event Periode

Berdasarkan gambar di atas, terlihat jika volume perdagangan saham diukur oleh trading volume activity memiliki rata-rata yang bervariasi. Jika melihat periode waktu sebelum dilaksanakan stock split (t-4 sampai t-1), rata-rata volume perdagangan saham paling tinggi yaitu t2 sejumlah 0.000986963 , sedangkan t-4 sejumlah 0.000841277 dan t-3 sebesar 0.000984396 dan t1 sebesar 0.000848921 lebih rendah dibanding t-2. Hal ini terjadi karena investor banyak membeli saham pada perusahaan-perusahaan tersebut hanya pada $\mathrm{t}-2$, kemudian pada $\mathrm{t}-3$, kemudian $\mathrm{t}-1$ dan t-4 terlihat kurangnya investor bertransaksi di bursa. Pada saat stock split ( $\mathrm{t} 0$ ), rata-rata volume perdagangan saham lebih tinggi dibandingkan t-2 yaitu sebesar 0.001260734, ini dikarenakan banyak investor yang mengetahui terdapatnya pengumuman stock split dan dampak dari adanya stock split.

Volume perdagangan saham mulai menurun saat periode sesudah stock split $(\mathrm{t}+20.000818327$ dan $t+3$ sebesar 0.000980444$)$. Rata-rata paling tinggi terjadi pada $t+1$ yaitu sebesar 0.001074793 dan $\mathrm{t}+4$ sebesar 0.0010742 . Meningkatnya volume perdagangan saham ialah akibat dampak stock split. Dengan adanya stock split, angka nominal saham akan semakin menurun atau harga saham relatif lebih murah, sehingga banyak investor melakukan transaksi yang akhirnya akan menaikan likuiditas saham. 
Tabel 2. Wilcoxon Signed Rank Test

\begin{tabular}{|l|l|r|r|r|}
\hline \multicolumn{2}{|c|}{} & \multicolumn{1}{|c|}{ N } & Mean Rank & \multicolumn{2}{|c|}{ Sum of Ranks } \\
\hline Volume & $\begin{array}{l}\text { Negative } \\
\text { Panks }\end{array}$ & $9^{\mathrm{a}}$ & 19.22 & 173.00 \\
\cline { 2 - 6 } $\begin{array}{l}\text { Serdagangan } \\
\text { Perdagah - Volume } \\
\text { Sebelum }\end{array}$ & $\begin{array}{l}\text { Positive } \\
\text { Ranks }\end{array}$ & $21^{\mathrm{b}}$ & 13.90 & 292.00 \\
\cline { 2 - 6 } & Ties & $0^{\mathrm{c}}$ & & \\
\cline { 2 - 6 } & Total & 30 & & \\
\hline
\end{tabular}

\begin{tabular}{|l|r|}
\hline \multicolumn{2}{|c|}{ Test Statistics } \\
\hline & \multicolumn{2}{|c|}{$\begin{array}{c}\text { Volume Perdagangan Sesudah - Volume } \\
\text { Perdagangan Sebelum }\end{array}$} \\
\hline$Z$ & \multicolumn{2}{|c|}{$-1.224^{\mathrm{b}}$} \\
\hline Asymp. Sig. (2-tailed) & \\
\hline
\end{tabular}

Sumber: Diolah Peneliti (Agustus, 2019)

Hasil Uji Wilcoxon Signed Rank Test pada periode sebelum dan sesudah peristiwa stock split dilakukan uji beda variabel volume perdagangan saham sebelum dan sesudah stock split menunjukkan nilai $\mathrm{P}$ value (sig 2 tailed) sebesar 0,221 . Oleh karena $\mathrm{P}$ value (sig) $0,221>\alpha 0,05$, maka $\mathrm{H}_{1}$ ditolak dan $\mathrm{H}_{0}$ diterima. Artinya tidak terdapat perbedaan yang signifikan volume perdagangan saham pada saat periode sebelum dan sesudah pemecahan saham.

\section{Analisis Perbandingan Volume Perdagangan Saham}

Hasil penelitian membuktikan secara statistik tidak adanya perbedaan volume perdagangan saham yang signifikan sebelum dan sesudah stock split. Sehingga hipotesis menyatakan bahwa terdapatnya perbedaan volume perdagangan saham sebelum dan sesudah perubahan nominal saham tidak terbukti. Pada grafik trading volume activity sebelumnya dapat dilihat bahwa nilai rata-rata volume perdagangan ( $\mathrm{t}-4$ sampai $\mathrm{t}+1)$ memberikan gambaran pada saat pengumuman stock split berlangsung terdapat banyak investor yang menerima dengan baik informasi atau pengumuman stock split dikarenakan jumlah volume perdagangan saham sangat meningkat. Namun kenyataannya hasil uji statistik menyatakan bahwa tidak terdapatnya perbedaan yang signifikan volume perdagangan saham antara sebelum dan sesudah periode stock split.

Trading range theory mengatakan dengan melakukan stock split akan meningkatkan likuiditas perdagangan saham tidak terbukti. Hasil penelitian justru membuktikan tidak adanya perbedaan volume perdagangan saham yang signifikansi sebelum dan sesudah stock split. Tidak terdapatnya perbedaan tersebut dapat diartikan investor menganggap bahwa pengumuman stock split bukanlah berita yang baik, oleh karena itu tidak terdapatnya perbedaan yang signifikan dan menunjukkan tidak terlalu diminatinya saham tersebut oleh investor. Volume perdagangan saham sesudah penyampaian stock split mengakibatkan fluktuasi, hal ini dapat dikatakan bahwa pasar kemungkinan dalam kondisi kurang baik, sehingga tidak terdapat perbedaan setelah pengumuman stock split atau jikalau ada kemungkinan perbedaannya hanyalah kecil.

Signalling theory berpendapat jika stock split dapat menginformasikan sinyal baik ke investor terbukti karena terdapat 21 perusahaan yang memiliki nilai positif dan hanya terdapat 9 perusahaan 
yang memiliki nilai negatif, akan tetapi hasil penelitian justru stock split tidak menunjukkan perbedaan atau hasil yang tidak signifikan kepada para investor yang ingin melakukan pemecahan saham. Oleh sebab itu, hal ini dapat diartikan pengumuman stock split tidak terlalu mempengaruhi keputusan para investor dalam berinvestasi, bahkan cenderung berhati-hati dalam mengambil keputusan. Sehingga para investor mempelajari pengumuman stock split terlebih dahulu sehingga tidak melakukan kesalahan dalam pengambilan keputusan. Investor mempelajari terlebih dahulu bagaimana kandungan informasi yang dimiliki stock split menguntungkan atau tidak, selain itu melihat kondisi fundamental perusahaan, image perusahaan, serta memperhatikan keadaan perekonomian dan pasar modal Indonesia.

Weston dan Copeland (2010) berpendapat jika likuiditas pasar dilakukan dapat memberikan saham menjadi menurun sesudah stock split. Meskipun perusahaan memiliki kinerja yang baik dan prospek yang menguntungkan di waktu mendatang, ternyata belum ditanggapi secara positif oleh pelaku pasar dengan dilakasanakan kebijakan stock split. Harahap (2007) mengatakan apabila pihak penawaran umum tidak memiliki prospek yang menarik bagi para pelaku pasar, oleh sebab itu volume perdagangan saham tersebut tidak akan terpengaruh banyak atau efeknya hanya sementara. Kemudian Kiswoyo (2017) mengatakan harga saham emiten-emiten yang telah melaksanakan stock split biasanya sudah turun, sehingga sulit untuk naik tinggi. Selain itu, perlu dilihat juga kinerja fundamental saham enam bulan ke depan. Jika volume dan nilainya tidak bertambah, maka sahamnya belum likuid. Tetapi jika terdapat penambahan, maka harga sahamnya pasti akan turut naik.

Hasil penelitian berbeda dengan penelitian terdahulu yang dilakukan Indarti dan Purba (2011), judul analisis perbandingan harga saham dan volume perdagangan saham sebelum dan sesudah stock split bahwa terdapat perbedaan yang signifikan antara volume perdagangan sebelum dan sesudah peristiwa pemecahan saham. Tujuan utama dilaksanakan stock split ialah untuk menaikan likuiditas saham. Kebijakan stock split dilakukan agar saham dapat menurun dibandingkan sebelumnya, sehingga diharapkan volume perdagangan saham dapat meningkat.

Sedangkan penelitian yang dilakukan Shofa dan Utiyati (2016) serta Firmansyah dan Agustin (2016) mendukung hasil penelitian yang menyatakan tidak adanya perbedaan yang signifikansi terhadap volume perdagangan saham sebelum dan sesudah stock split. Tidak terdapatnya perbedaan yang signifikan trading volume activity sebelum dan sesudah pemecahan saham salah satunya bisa dikarenakan para calon investor menerima informasi pengumuman pemecahan saham sebagai informasi yang kurang baik.

\section{KESIMPULAN DAN SARAN}

Berdasarkan hasil penelitian yang telah dilakukan pada bab sebelumnya maka dapat disimpulkan bahwa tidak terdapat perbedaan volume perdagangan saham yang signifikan sebelum dan sesudah melakukan pemecahan saham. Oleh karena itu dapat diketahui bahwa stock split bukanlah penentu yang baik bagi calon investor dalam berinvestasi, sehingga dalam berinvestasi investor dapat melihat dari kondisi fundamental perusahaan, mengetahui lebih detail produk investasi, modal atau kesanggupan calon investor, dividen, profit dan potensi gain dari selisih untung antara harga jual dan beli.

Berdasarkan hasil penelitian dan pembahasan yang dibuat dalam suatu kesimpulan, maka peneliti memberikan saran-saran sebagai berikut:

1) Bagi manajemen perusahaan, khususnya pada perusahaan manufaktur bahwa dengan melakukan stock split tidaklah selalu berpengaruh signifikan terhadap harga saham perusahaan maupun citra perusahaan, karena sesudah dilakukan stock split harga saham suatu perusahaan justru jatuh dan rendahnya volume perdagangan saham. 
2) Bagi investor, sebagai pertimbangan untuk berinvestasi terkhusus pada perusahaan manufaktur agar melihat dengan baik informasi yang disampaikan manajemen perusahaan mengenai prospek return substansial kedepannya. Perusahaan yang memberikan informasi baik mengenai return di masa mendatang belum tentu dapat memberikan keuntungan maksimal kepada investor.

3) Bagi akademis yang ingin meneliti dengan topik yang sama, agar menambah variabel pembeda, seperti earning atau dividen serta menambah periode pengamatan lebih panjang sebelum melakukan stock seperti tujuh hari sebelum melakukan stock split dan tujuh hari sesudah melakukan stock split atau bahkan 15 hari sebelum melakukan stock split dan 15 hari sesudah melakukan stock split dan menambah periode penelitian (tujuh tahun terakhir). Kemudian semua perusahaan yang terdaftar di BEI dan melakukan stock split dijadikan sebagai populasi, serta kriteria penentuan sampel ditambah.

\section{REFERENSI}

Ayu, K. (2011). Perbedaan volume perdagangan saham sebelum dan sesudah reverse stock split pada perusahaan.

Anggraini, Rahayu, dan Topowijono. 2014. Penerapan Model Multiple Discriminant Analysis Untuk Memprediksi Financial Distress . Jurnal Administrasi Bisnis Vol.8.No.2 Maret 2014 Administrasibisnis.studentjournal.ub.ac.id:

Anshuman, V. R., \& Kalay, A. (2002). Can splits create market liquidity? Theory and evidence. Journal of Financial Markets, 5(1), 83-125. (Leungb, et al. 2006)

Darmadji, Tjiptono dan Hendy Fakhruddin, 2008. Pasar Modal di Indonesia Pendekatan Tanya Jawab. Jakarta: Salemba Empat

Foster, George.1986. Financial Statement Analysis. Second Edition. Prentice Hall International. Englewood Cliffs, New Jersey.

Ghozali, Imam. 2009. Aplikasi Analisis Multivariate Dengan Program SPSS. Cetakan Keempat. Semarang: Badan Penerbit Universitas Diponegoro.

Gunaasih dan Nursasmito, Irfan, (2015), The Evaluation of Non-Ecoomic Even Towards the LQ45 I ndex in I ndonesia Stock Exchange by using Event Study Method, Integrative Busines \& Economic Research, vol. 4, No. 2.

Harahap, Sofyan Syafri. 2007. Analisis Kritis atas Laporan Keuangan. Jakarta: PT Raja Grasindo Persada.

Hasna, Chotyahani. 2010. Analisis Pengaruh Stock Split Terhadap Harga Saham Pada Perusahaan Go Public di Bursa Efek Indonesia. Skripsi S-1: Jurusan Akutansi Fakultas Ekonomi Universitas Diponegoro Semarang. Semarang.

Hadi, Nor. 2013. Pasar modal. Yogyakarta : Graha Ilmu

Hendrawaty, Ernie. 2007. Pengujian Efesiensi Pasar Modal atas Peristiwa Pengumuman Stock Split Periode tahun 2005-2006 di BEI. ISSN vol 2 No.2). International Journal of Economics and Finance, 6(5), 33

Inayatus Shofa. (2016). "Analisis Perbandingan Harga dan Volume Perdagangan Saham Sebelum dan Sesudah Stock Split. Jurnal Ilmu dan Riset Manajemen,Vol. 5, No. 7, ISSN : 2461 0593.

Kiswoyo Adi Joe. 2017. Lima Saham Ini Tancap Gas Sepanjang Januari 2017,Berikan Return Lebih Dari 50\%. Bareksa.com.

Larasanti. Ni 2017, "Analisis Pengaruh Pemecah Saham (Stock Split)TerhadapHargaSaham dan Volume Perdagangan Saham Pada Perusahaan Yang TerdaftarDi Bursa Efek Indonesia Tahun 2006-2015", Skripsi, Universitas Sanata Dharma, Yogyakarta.

Martalena dan Maya Malinda. (2011). Pengantar Pasar Modal. Bandung : Andi Yogyakarta. 
Mahala, F. L., \& Zahroh, Z. A. (2015). STOCK SPLIT ( Studi Pada Perusahaan Terdaftar Yang Melakukan Stock Split di Bursa Efek Indonesia tahun 2012-2014 ), 25(1), 1-7.

Mahala Fifi Lailatul. 2015. Analisis Harga Saham Sebelum dan Sesudah Pengumuman Stock Split. Jurnal Administrasi Bisnis. Vol. 25. No. 1.

Mulyani, D., \& Purba, B. R. (2011). Analisis Perbandingan Harga Saham dan Volume Perdagangan Saham Sebelum dan Sesudah Stock Split, 13(1), 57-63.

Pramana, Andi dan Wisnu Mawardi. 2012. Analisis Perbandingan Trading Volume Activity dan Abnormal Return Saham Sebelum dan Sesudah Pemecahan Saham. Journal Management. Vol. 1 No 1. Semarang.

Purba, Terkelin. 2017. Analisis Komparasi Abnormal Return dan Volume Perdagangan Saham Atas Pemberlakuan Peraturan Pemerintah Nomor 1 Tahun 2014. Jurnal Riset Bisnis dan Manajemen. Vol. 5. No. 1.

Purbawati,dkk. 2016. Pengaruh Pemecahan Saham (Stock Split) Terhadap Trading Volume Activity dan Average Abnormal Return pada Perusahaan yang Terdaftar di BEI. Journal Of Accounting. Vol. 2 No 2. Semarang.

Saputra, Indra. 2017. Perbedaan Harga Saham Sebelum dan Sesudah Pengumuman Stock Split Pada Perusahaan yang Listing di Bursa Efek Indonesia Periode 2008-2013. Jurnal Ekonomi dan Bisnis. Vol. 10. No. 1.

Sakti, Paramita Oktaviana dan Irene Rini. 2013. Analisis Pengaruh Stock Split Terhadap Abnormal Return dan Volume Perdagangan Saham pada Perusahaan Tumbuh dan Tidak Tumbuh. Journal Of Management.Vol. 2 No 3. Semarang.

Septina, N. (2017). Analisis Perbandingan Harga Saham, Jumlah Transaksi, Volume Perdagangan, Dan Resiko Sebelum dan Sesudah Perubahan Fraksi Harga Saham Pada Perusahaan Manufaktur yang Terdaftar Di Bursa Efek Indonesia. Analisis Perbandingan Harga Saham, Jumlah Transaksi, Volume Perdagangan, Dan Resiko Sebelum Dan Sesudah Perubahan Fraksi Harga Saham Pada Perusahaan Manufaktur Yang Terdaftar Di Bursa Efek Indonesia.

Slamet Riyadi dan Selvi Andreva. (2013). "Analisis Dampak Stock Split terhadap Harga, Volume dan Keputusan Investasi Pada Saham”. E - Jurnal Manajeme dan Bisnis, Vol 1, No 1, ISSN: $2355-0244$.

Shofa Inayatus, Utiyati Sri 2016. Analisis Perbandingan Harga Dan Volume Perdagangan Saham Sebelum Dan Sesudah Stock Split. Surabaya: STIESIA. Vol.5. No.7.

Sugiyono. 2013. Metode Penelitian Kuantitatif, Kualitatif, dan Kombinasi (Mixed Methods). Bandung: Alfabeta.

Suryanto dan Muhyi, Herwan Abdul. 2017. Analisis Perbandingan Saham Sebelum dan Sesudah Stock Split di Bursa Efek Indonesia. Bandung: Universitas Padjadjaran. Vol. VII. No. 2.

Tandelilin, Eduardus. (2010). Portofolio dan Investasi Teori dan Aplikasi. Edisi Pertama. Yogyakarta : Kanisius.

Tandelilin, Eduardus. (2015). Portofolio dan Investasi. Edisi Pertama: Konisius. Brigham Eugene F. dan Houston Jol F. (2011). Dasar - dasar Manajemen Keuangan. Edisi Ke sebelas. Jakarta: Salemba Empat

Weston, Fred. J dan Thomas, E Copeland. 2010. Manajemen Keuangan. Edisi Kesepuluh. Jakarta : Binarupa Aksara.

Yasa, Utama. 2017. Analisis Komparatif Volume Perdagangan dan Abnormal Return Saham Pada Perusahaan yang Terdaftar di BEI Sebelum dan Sesudah Pemecahan Saham. Singaraja: Ejournal S1 Ak Universitas Pendidikan Ganesha. Vol. 8 No. 2. 